\title{
Pengaruh PDRB, PAD, dana berimbang, SiLPA terhadap belanja modal pada Kabupaten/Kota Provinsi Sumatera Utara Tahun 2013-2017
}

\section{Neta Erniwati Telaumbanua*; Megawati Doloksaribu; Cici Debora Sirait; Yois Nelsari Malau}

\author{
Prodi Akuntansi, Fakultas Ekonomi, Universitas Prima Indonesia, Medan \\ *E-mail korespodensi: netaerniwatitel@gmail.com
}

\begin{abstract}
The purpose of this presentation is to determine the effect of calculating regional domestic income, local revenue, balancing funds, and excess budget on the Special Capital Expenditure of the Regency / City of North Sumatra Province in 2013-2017. This presentation uses a descriptive quantitative presentation type. The number of samples is 28 districts/cities. The sample selection is done by using purposive sampling. how to collect data with documentation techniques, and taken from secondary data. The data were tested by statistical data analysis in the form of multiple linear regression analysis where the classical assumption test was carried out first using SPSS. The value of Adjusted $R$ square is 0.571 , meaning that $57.1 \%$ of the capital expenditure variable can be applied by independent variables and the remaining $42.9 \%$ can be applied by variables that have not been made in this study.
\end{abstract}

Keywords: Balancing fund, Capital expenditure, Excess budget calculation

\begin{abstract}
Abstrak
Tujuan penyajian ini adalah untuk mengetahui pengaruh penghitungan pendapatan domestik regional bruto, pendapatan asli daerah, dana perimbangan, dan sisa lebih perhitungan anggaran terhadap belanja modal khusus di Kabupaten / Kota Provinsi Sumatera Utara tahun 2013-2017. Penyajian ini menggunakan jenis penyajian deskriptif kuantitatif. Jumlah sampel sebanyak 28 Kabupaten/Kota. Pemilihan sampel dilakukan dengan menggunakan purposive sampling. cara mengumpulkan data dengan teknik dokumentasi, dan diambil dari data sekunder. Data diuji dengan analisis data statistik berupa analisis regresi linier berganda dimana terlebih dahulu dilakukan uji asumsi klasik dengan menggunakan SPSS. Nilai Adjusted R square sebesar 0,571, artinya 57,1\% variabel belanja modal dapat diterapkan oleh variabel independen dan sisanya $42,9 \%$ dapat diterapkan oleh variabel yang belum dibuat dalam penelitian ini.
\end{abstract}

Kata kunci: Dana perimbangan, Belanja modal, Sisa lebih perhitungan anggaran

\section{PENDAHULUAN}

Terwujudnya keinginan masyarakat untuk mencapai tujuan dan cita negara adalah hal terpenting di dalam terselenggaranya pemerintahan yang baik. Otonomi daerah ialah sebuah kebebasan pemerintah daerah didalam mengambil keputusan dalam mengolah, 
mengatur, mengawasi, dan mengoptimalkan sumber daya yang ada disuatu daerah tertentu. Anggaran BM ada karena adanya kepentingan daerah, contohnya kelancaran terlaksananya tugas pemerintahan juga untuk fasilitas publik. Belanja modal merupakan bagian dari salah satu anggaran pemerintah daerah dan tergolong dalam jenis belanja langsung dimana anggarannya langsung terkait dengan pelaksanaan rencana maupun kegiatan pemerintah lainnya. BM berkaitan dengan kegiatan pemerintah yang dapat menambah asset daerah tetapi juga mengurangi kas daerah, maka sangatlah penting bagi pemerintah daerah dalam memperhatikan tingkat atau system akuntansi belanja modal dalam suatu daerah tertentu.

Pemerintah daerah di Sumatera Utara masih harus memprioritaskan belanja modal dari pada belanja lainnya di dalam anggaran belanja daerahnya. PDRB sebagian tergolong sebagai sumber dalam melihat kondisi juga keadaan ekonomi sebuah daerah selama satu periode akuntansi. Baik itu dasar harga konstan ataupun dasar harga berlaku. Salah satu pendapatan biaya yang terpenting untuk Pemerintah ialah PAD (Pendapatan Asli Daerah). Besar kecilnya PAD bisa meningkatkan maupun mengurangi ketergantungan daerah kepada pusat pemerintah. Penerimaan PAD ialah bersumber dari pajak daerah, hasil pengelolaan kekayaan daerah yang dipisahkan, retribusi daerah serta lain-lain pendapatan asli daerah yang sah.

Pemerintah selalu berusaha dalam memberikan perhatian yang besar kepada penerapan desentralisasi fiscal dengan cara instrumen transfer kedaerah. Sebagai salah satunya adalah dana perimbangan. DB sumbernya dari dana transfer APBN yang diberikan untuk daerah guna membiayai kebutuhan suatu daerah dalam hal penerapan desentralisasi (UU No. 33 Tahun 2004 tentang dana berimbang antar pemerintah daerah dengan pemerintah pusat).

Anggaran pembiayaan daerah berasal oleh SiLPA, dana cadangan daerah, pinjaman daerah, dan penjualan kekayaan daerah yang dipisahkan. SiLPA yang digunakan untuk tahun anggaran selanjutnya dapat membiayaai perencanaan berikutnya oleh kewajiban belanja langsung, diantaranya belanja jasa dan barang, belanja pegawai dan juga belanja modal. Sisa lebih perhitungan anggaran (SiLPA) dipakai jika suatu daerah mendapati defisit APBD untuk menaikkan kapasitas layanan serta kenyamanan rakyat semasa periode berlanjut.

PDRB, PAD, dana berimbang, dan SiLPA mengalami kenaikan dalam setiap tahunnya. Namun ada beberapa daerah yang pada tahun tertentu mengalami penurunan anggaran. Sebagai salah satu contohnya Hubungan antara variabel PDRB kepada belanja modal tidak sejalan, masalah ini dapat dilihat dari laporan keuangan bpssumut.go.id. Hal ini ditunjukkan pada variabel PDRB tahun 2013-2017 pada kabupaten Tapanuli Selatan yang mengalami peningkatan dalm setiap tahunnya. Namun tidak diikuti dengan belanja modal pada tahun 2013-2017 dimana dalam tahun tertentu mengalami penurunan. Dalam hal ini peneliti mengindikasikan hubungan antara PDRB terjadi masalah dengan BM.

Hal serupa juga terjadi kepada PAD, dana berimbang, dan SiLPA yang kadang mengalami kenaikan dan penurunan dalam tahun tertentu namun tidak diikuti oleh oleh belanja modal yang mana hal tersebut dapat diindikasikan bahwa adanya masalah antara PAD, dana berimbang, dan SiLPA terjadi masalah kepada BM. Berdasarkan kajian masalah diatas membuat peneliti tertarik untuk menganalisis dan meneliti serta menuangkan ke dalam bentuk tulisan yang diberi judul "Pengaruh produk domestik regional bruto, PAD, dana berimbang, dan SiLPA terhadap BM pada Kabupaten/Kota Provinsi Sumatera Utara Tahun 2013-2017'. 


\section{LANDASAN TEORI}

\section{Teori pengaruh Produk Domestik Regional Bruto terhadap belanja modal}

Menurut BPS (2016:3) PDRB adalah nilai tambah brutto semua jasa dan barang yang dihasilkan diwilayah sebuah Negara dan timbul karena adanya kegiatan ekonomi dalam suatu periode. PDRB ialah hasil nilai tambah dan didapatkan oleh semua aktivitas produksi untuk perekonomian suatu daerah, (Adisasmita, 2014:26). Menurut Hartati (2014) dalam jurnal, PDRB yang nilainya besar selalu memiliki belanja modal yang besar.

\section{Teori pengaruh pendapatan asli daerah terhadap belanja modal}

Berdasarkan UUD Nomor 33 Tahun 2004 tentang dana berimbang keuangan antar pemerintah daerah terhadap pusat mengatakan ialah PAD merupakan pendapatan yang didapatkan daerah dan dikutip berdasarkan UU. PAD ialah dana yang dihasilkan daerah yang dipungut atas dasar aturan daerah yang didasarkan oleh UU Pasal I angka 18, (Halim, 2014:169). Dalam jurnal Rizal dkk (2019), apabila PAD naik maka belanja modal juga akan mengalami kenaikan.

\section{Pengaruh dana berimbang terhadap belanja modal}

Menurut Siregar (2017:82) dana berimbang ialah dana yang dialokasikan didalam APBN buat daerah dalam hal membiayai kebutuhan-kebutuhan daerah dalam tujuan melakukan desentralisasi. Dalam BPS (2017:5) dana berimbang merupakan suatu dana yang berasal oleh penghasilan APBN dan diberi untuk daerah dalam rangka pelaksanaan desentralisasi. Menurut Nufus dkk (2017) dalam jurnal, pemerintah pusat memberikan dana perimbangan dengan tujuan menciptakan keadilan dan kesejahteraan sumberdaya baik kepentingan nasional maupun kepentingan rakyat.

\section{Pengaruh sisa lebih pembiayaan anggaran terhadap belanja modal}

SiLPA ialah pendapatan daerah yang berasal dari sisa Asset di tahun anggaran sebelumnya (Halim 2013). Menurut Sujarweni (2015:70) SiLPA ialah perbandingan antara pengeluaran dengan sisa lebh realisasi pendapatan selama satu tahun. Menurut BPS (2017:12) SiLPA merupakan pos yang dibuat guna mengetahui biaya bersih, dimana berupa perbandingan atas pengeluaran pembiayaan antar pengeluaran dengan pengeluaran pembiayaan.

\section{METODE}

\section{Populasi dan Sampel}

Populasi ialah wilayah generasi yang terdiri dari subjek dan objek yang memiliki kualitas dan karakter tertentu yang ditetapkan oleh penelitian guna untuk dipelajari lalu kemudian dibuat kesimpulannya (Sugiono, 2016:80). Teknik pengambilan sample dibuat dengan menggunakan metode purposive sample. Populasi terdiri dari 33 kabupaten/kota Provinsi Sumatera Utara. Jumlah data sebanyak 104 dengan 5 tahun pengamatan.

\section{HASIL DAN PEMBAHASAN}

\section{Statistik deskriptif}

Descriptive statistic bagi setiap variable yang mana variable bebas yaitu PDRB, PAD, DB, SiLPA dan variabel dependen yaitu Belanja Modal. Jumlah data observasi sebanyak 140 dengan 5 tahun pengamatan. Data statistic dari seluruh data statistic variable yang dipergunakan dalam pembahasan ini merupakan berikut ini: 
Jurnal Paradigma Ekonomika Vol.16.No.1, Januari -Maret 2021 ISSN: 2085-1960 (print); 2684 -7868 (online)

Tabel 1. Statistik deskriptif

\begin{tabular}{lcrrrr}
\hline & N & Minimum & Maximum & \multicolumn{1}{c}{ Mean } & \multicolumn{1}{c}{ Std. Deviation } \\
\hline PDRB & 140 & 20,218336 & 24,897528 & 22,55359188 & 1,011658162 \\
PAD & 140 & 22,700632 & 27,467662 & 24,74402532 &, 816849104 \\
D.BERIMBAN & 140 & 26,439410 & 28,317929 & 27,24230660 &, 390719573 \\
G & 140 & 21,123625 & 26,541112 & 24,88387744 &, 796573484 \\
SiLPA & 140 & 25,189867 & 27,331883 & 26,06687307 &, 370630078 \\
B.MODAL & 140 & & & & \\
Valid N & & & & \\
(listwise) & & & & & \\
\hline
\end{tabular}

Sumber: Data diolah, 2020

Berdasarkan Tabel 1 bisa diketahui total sample, nilai terkecil, nilai terbesar, nilai rata-rata serta standard deviation berdasarkan dari variable PDRB, PAD, DB, SiLPA serta Belanja Modal ialah berikut ini: PDRB pada Kabupaten/Kota Provinsi Sumatera Utara tahun 2013-2017 dengan nilai terendah adalah 20,21836 diperoleh kota Pakpak Barat pada tahun 2013 dan tertinggi adalah 24,897528 diperoleh kota Deli Serdang pada tahun 2017, hasil mean 22,55359188 serta standard deviation 1,011658162.

PAD di kabupaten/kota Provinsi Sumatera Utara tahun 2013-2017 nilai minimum ialah 22,700632 diterima oleh kota Nias Barat dalam tahun 2013, juga nilai maximum ialah 27,467662 diterami oleh Deli Serdang pada tahun 2017, hasil mean 24,74402532 serta standard Deviation 0,816849104. DB pada Kabupaten/Kota Provinsi Sumatera Utara tahun 2013-2017 dalam nilai teredah adalah 26,439410 diperoleh kota Nias Barat pada tahun 2013 dan nilai tertinggi adalah 28,317929 diperoleh kota Deli Serdang pada tahun 2017, mean 27,24230660 serta standard deviation 0,390719573.

SiLPA di Kabupaten/Kota Provinsi Sumatera Utara pada tahun 2013-2017 dalam nilai terendah adalah 21,123625 diperoleh kota Simalungun dalam tahun 2013 dan juga nilai maximum ialah 26,541112 diterima oleh Kota Karo dalam tahun 2016, mean 24,88387744 serta standard deviation 0,796573484. BM pada Kabupaten/Kota Provinsi Sumatera Utara tahun 2013-2017 dalam nilai terendah adalah 25,189867 diperoleh kota Sibolga dalam tahun 2013 dan nilai tertinggi adalah 27,331883 diperoleh kota Deli Serdang pada tahun 2017, mean 26,06687307 serta standard deviation 0,370630078.

\section{Hasil uji asumsi klasik}

Uji normalitas

Gambar Gambar 1 menunjukkan bahwa sebagian besar ada didalam kurva serta membentuk simetris. Hal ini menunjukkan bahwa hasil berdistribusi normal.

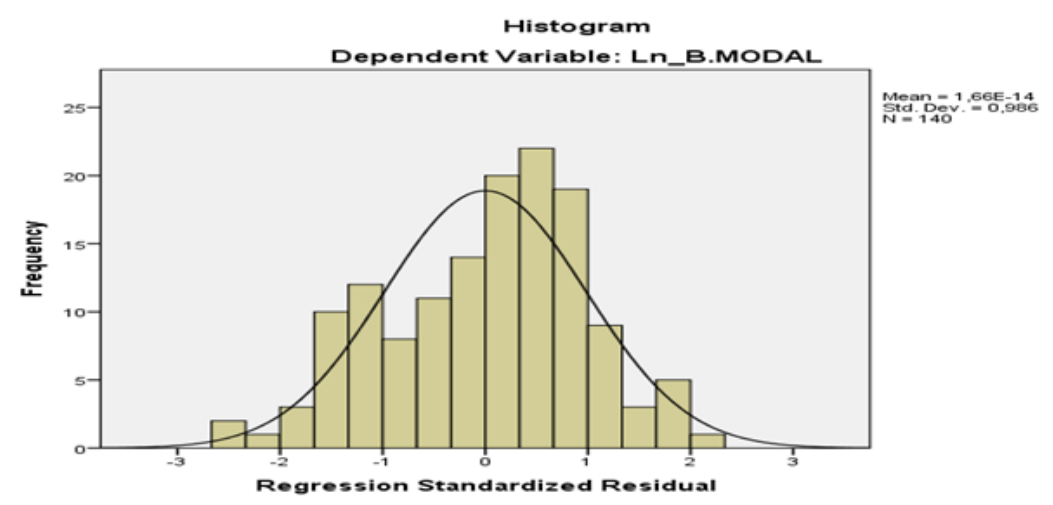

Sumber: Data diolah, 2020

Gambar 1. Grafik histogram 
Selain itu pada Gambar 2. garis diagonal terlihat diikuti oleh titik-titik, maka bisa dikatakan data ini berdistribusi normal.

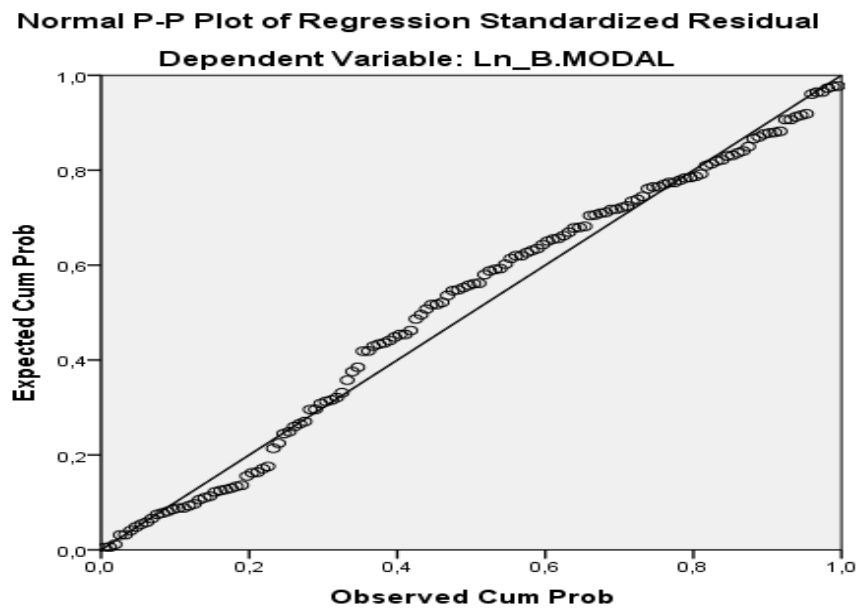

Sumber: Data diolah, 2020

Gambar 2. Normal P-P Plot of Regression

Hasil pengolahan data pada tabel dapat diterima hasil nilai Kolmogorov-Smirnov Z 0,891 juga Asyimp.Sig adalah 0,405>0,05 dalam kata lain variable residual berdistribusi normal.

Tabel 2. Uji Kolmogorov-Smirnov $(K-S)$

\begin{tabular}{llr}
\hline & & $\begin{array}{c}\text { Unstandardized } \\
\text { Residual }\end{array}$ \\
\hline $\mathrm{N}$ & Mean & 140 \\
Normal Parameters ${ }^{\mathrm{a}, \mathrm{b}}$ & Std. Deviation &, 00914203 \\
& Absolute &, 075 \\
Most Extreme Differences & Positive &, 060 \\
& Negative &,- 075 \\
Kolmogorov-Smirnov Z & &, 891 \\
Asymp. Sig. (2-tailed) & &, 405 \\
\hline Sumber: Data diolah, 2020 & &
\end{tabular}

Pengujian Tabel 3 tersebut, menyatakan hasil uji multikolonieritas bisa dilihat bahwa jumlah Tolerance PDRB, PAD, DB, dan SiLPA > 0,10 sedangkan nilai VIF < 10 maka penelitian ini bisa dinyatakan tidak ada terjadi multikolonieritas.

Tabel 3. Uji multikolinearitas

\begin{tabular}{llcc}
\hline \multirow{2}{*}{ Model } & \multicolumn{2}{c}{ Collinearity Statistics } \\
\cline { 2 - 4 } (Constant) & Tolerance & VIF \\
\hline \multirow{2}{*}{1 Ln_PDRB } & Ln_PAD &, 295 & 3,392 \\
& Ln_D.BERIMBANG &, 367 & 2,726 \\
& Ln_SiLPA &, 216 & 4,623 \\
& &, 963 & 1,038 \\
\hline
\end{tabular}

Sumber: Data diolah, 2020 
Selanjutnya, pada Tabel 4 menunjukkan hasil uji Autokorelasi didapat nilai DW sejumlah 1,787 setelah dihitung memperoleh nilai $\mathrm{dl}=1,6656, \mathrm{du}=1,7830 \mathrm{dan} 4$-du $=$ 2,217, maka du $<\mathrm{dw}<4$-du $(1,7830<1,787<2,217)$ maka ini menunjukkan bahwa autokorelasi tidak terjadi baik positif maupun negatif.

Tabel 4. Uji autokorelasi

\begin{tabular}{|c|c|c|c|c|c|}
\hline Mode & $\mathbf{R}$ & R Square & $\begin{array}{l}\text { Adjusted R } \\
\text { Square }\end{array}$ & $\begin{array}{l}\text { Std. Error of the } \\
\text { Estimate }\end{array}$ & $\begin{array}{l}\text { Durbin- } \\
\text { Watson }\end{array}$ \\
\hline 1 &, $763^{a}$ & ,583 & ,571 & ,00928 & 1,787 \\
\hline
\end{tabular}

Sumber: Data diolah, 2020

\section{Uji heteroskedastisitas}

Hasil gambar dibawah menunjukkan titik-titik data memencar dengan jelas yaitu ada yang dibawah dan juga diatas di antara angka nol (0) kepada sumbu Y, jadi dapat disimpulan hasil penelitian tidak terbentuk Heteroskedastisitas.

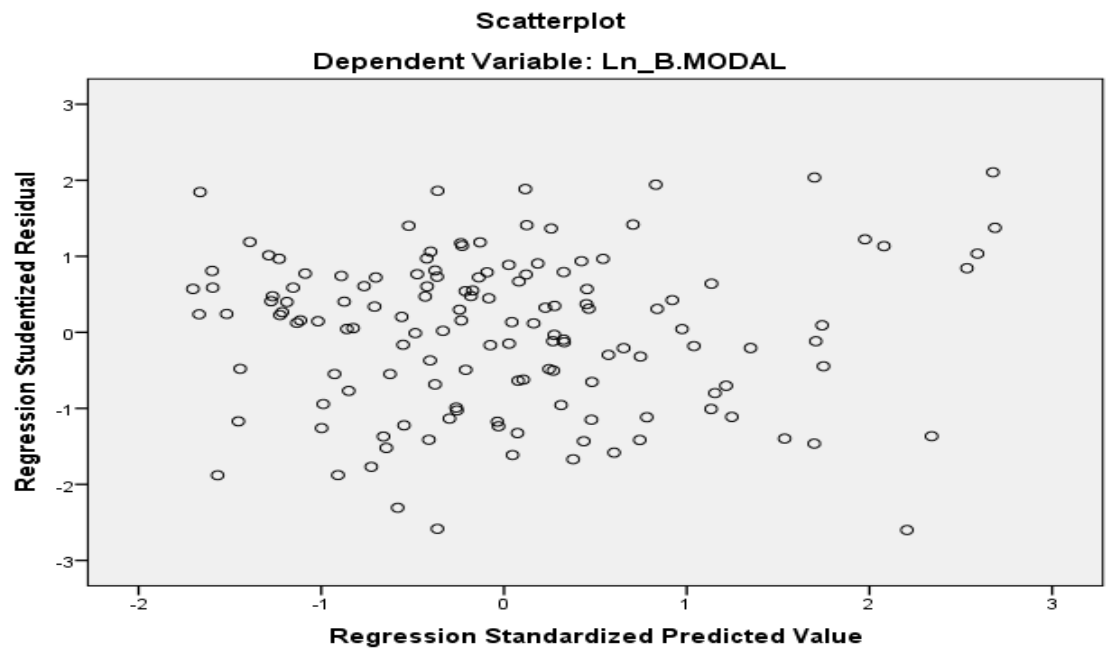

Sumber: Data diolah, 2020

Gambar 3. Grafik scatterplot

Selanjutnya, berdasarkan Tabel 5 menunjukkan hasil pengujian gletser diatas terlihat variabel PDRB memiliki nilai signifikan 0,287, variabel PAD nilai signifikan 0,403, variabel DB nilai signifikan 0,987, variabel SiLPA nilai signifikan 0,210. Maka disimpulkan bahwa tidak terdapat Heteroskedastisitas, dengan nilai signifikan variabelvariabel tersebut $>0,05$.

Tabel 5. Hasil uji Gletser

\begin{tabular}{|c|c|c|c|c|c|c|}
\hline & \multirow[t]{2}{*}{ Model } & \multicolumn{2}{|c|}{$\begin{array}{c}\text { Unstandardized } \\
\text { Coefficients }\end{array}$} & \multirow{2}{*}{$\begin{array}{c}\begin{array}{c}\text { Standardized } \\
\text { Coefficients }\end{array} \\
\text { Beta }\end{array}$} & \multirow[t]{2}{*}{$\mathbf{t}$} & \multirow[t]{2}{*}{ Sig. } \\
\hline & & B & Std. Error & & & \\
\hline \multirow{5}{*}{1} & (Constant) &,- 052 & 149 & &,- 352 & ,725 \\
\hline & Ln_PDRB & 019 & ,018 &, 163 & 1,069 & 287 \\
\hline & Ln_PAD &, 018 & ,022 &, 115 & ,839 & ,403 \\
\hline & Ln_D.BERIMBANG &,- 001 & ,066 &,- 003 &,- 016 & ,987 \\
\hline & Ln_SiLPA &,- 017 & 014 &,- 106 & $-1,258$ & 210 \\
\hline
\end{tabular}

Sumber: Data diolah, 2020 
Tabel 6. Hasil uji regresi linear berganda

\begin{tabular}{|c|c|c|c|c|c|c|c|c|}
\hline & \multirow{2}{*}{ Model } & \multicolumn{2}{|c|}{$\begin{array}{l}\text { Unstandardized } \\
\text { Coefficients }\end{array}$} & \multirow{2}{*}{$\begin{array}{c}\text { Standardized } \\
\text { Coefficients } \\
\text { Beta }\end{array}$} & \multirow[b]{2}{*}{$\mathbf{t}$} & \multirow{2}{*}{ Sig. } & \multicolumn{2}{|c|}{$\begin{array}{l}\text { Collinearity } \\
\text { Statistics }\end{array}$} \\
\hline & & B & Std. Error & & & & $\begin{array}{c}\text { Toleran } \\
\text { ce }\end{array}$ & VIF \\
\hline \multirow{5}{*}{1} & (Constant) & ,792 & 269 & & 2,943 & 004 & & \\
\hline & Ln_PDRB & ,058 & ,032 & , 184 & 1,798 & ,074 & ,295 & 3,392 \\
\hline & Ln_PAD &,- 080 & ,039 &,- 185 & $-2,020$ & ,045 & ,367 & 2,726 \\
\hline & Ln_D.Berimbang & ,680 & ,118 & 685 & 5,736 & ,000 & ,216 & 4,623 \\
\hline & Ln_SiLPA & ,093 &, 024 & ,214 & 3,785 & ,000 & 963 & 1,038 \\
\hline
\end{tabular}

Sumber: Data diolah, 2020

\section{Ln_Belanja Modal $=0,792+0,058$ Ln_PDRB $-0,080$ Ln_PAD + 0,680 Ln_DB $+0,093$ Ln_SiLPA}

Penjelasan dari persamaan diatas : 1). Jumlah hasil constant yaitu 0,792 maksudnya jika nilai PDRB, PAD, DB, serta SiLPA dianggap konstan, jadi BM tahun 2013-2017 adalah 0,792. 2). PDRB berpengaruh positif terhadap nilai coefisient sebesar 0,058 maksudnya setiap pertamban Rp 1 PDRB akan menaikkan BM sebesar Rp 0,058. 3). PAD berpengaruh negatif terhadap nilai coefisient yaitu -0,080 maka setiap mengalami penurunan Rp 1 PAD dapat mengakibatkan penurunan terhadap BM sebesar $\mathrm{Rp}-0,080$. 4). DB berpengaruh positif terhadap nilai koefisien sebesar 0,680 maksudnya setiap pertambahan Rp 1 DB menaikkan BM sebesar Rp 0,680. 5). SiLPA mengalami pengaruh positif kepada nilai coefisient yaitu 0,093 maksudnya dalam mengalami pertambahan Rp 1 SiLPA menaikkan BM sebesar Rp 0,093.

Tabel 7. Koefisiensi determinasi $\left(\mathrm{R}^{2}\right)$

\begin{tabular}{clc}
\hline Model & R & Adjusted R Square \\
\hline 1 &, $763^{\mathrm{a}}$ &, 571 \\
\hline
\end{tabular}

Sumber: Data diolah, 2020

Dari Tabel 7 dapat disimpulkan bahwa hasil jumlah coefisient determinasi yang telah ditentukan oleh adjusted $R$ squere $\left(R^{2}\right)$ senilai 0,571 , maksudnya $57,1 \%$ variable terikat (BM) mampu diterapkan terhadap variable bebas diantaranya PDRB, PAD, DB, SiLPA, dan selebihnya sebesar $42,9 \%$ dijelaskan oleh variable lain di luar variable yang digunakan, contohnya, investasi, inflasi, tingkat tenaga kerja dan tingkat kemiskinan.

Tabel 8. Pengujian hipotesis secara simultan (uji F)

\begin{tabular}{llrrrrr}
\hline & Model & Sum of Squares & Df & Mean Square & F & Sig. \\
\hline \multirow{3}{*}{1} & Regression &, 016 & 4 &, 004 & 47,166 &, $000^{\mathrm{b}}$ \\
& Residual &, 012 & 135 &, 000 & & \\
& Total &, 028 & 139 & & & \\
\hline
\end{tabular}

Sumber: Data diolah, 2020

Tabel 8 dapat disimpulkan bahwa hasil dari uji statistc $\mathrm{F}$ akan menunjukan jumlah $F_{\text {hitung }}$ sebesar 47,166 dengan jumlah signifikan 0,000, sedangkan $F_{\text {tabel }}$ dengan jumlah 2,44. Maka disimpulkan $F_{\text {hitung }}>F_{\text {tabel }}$ ialah 47,166 $>2,44$ maka kesimpulannya adalah $\mathrm{H}_{0}$ ditolak $\mathrm{H}_{\mathrm{a}}$ diterima, maksudnya variable PDRB, PAD, DB, SiLPA adanya pengaruh signifikan kepada BM pada Kabupaten/Kota Provinsi Sumatera Utara Tahun 2013-2017. 
Tabel 9. Pengujian hipotesis secara parsial (uji t)

\begin{tabular}{|c|c|c|c|c|c|c|}
\hline & \multirow[t]{2}{*}{ Model } & \multicolumn{2}{|c|}{$\begin{array}{l}\text { Unstandardized } \\
\text { Coefficients }\end{array}$} & \multirow{2}{*}{$\begin{array}{c}\begin{array}{c}\text { Standardized } \\
\text { Coefficients }\end{array} \\
\text { Beta }\end{array}$} & \multirow[t]{2}{*}{$\mathbf{T}$} & \multirow[t]{2}{*}{ Sig. } \\
\hline & & B & Std. Error & & & \\
\hline \multirow{5}{*}{1} & (Constant) & ,792 & ,269 & & 2,943 & ,004 \\
\hline & Ln_PDRB &, 058 & 032 &, 184 & 1,798 & 074 \\
\hline & Ln_PAD &,- 080 & ,039 &,- 185 & $-2,020$ & 045 \\
\hline & Ln_D.Berimbang & ,680 & ,118 & ,685 & 5,736 & 000 \\
\hline & Ln_SiLPA & 093 &, 024 &, 214 & 3,785 & 000 \\
\hline
\end{tabular}

Sumber: Data diolah, 2020

Tabel 9 menunjukan hasil dari pengujian tabel t bisa menceritakan pengaruh variable bebas secara parsial ialah berikut ini: 1). Variable PDRB Memiliki nilai signifikan 0,074 dengan nilai $t_{\text {hitung }} 1,798$ dan jumlah $t_{\text {tabel }} 1,97756$ dan nilai signifikan 0,05 maka bisa disimpulkan bahwa nilai $t_{\text {hiting }}<\mathrm{t}_{\text {tabel }}(1,798<1,97756)$ dan nilai

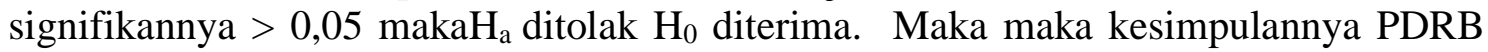
tidak bukan berpengaruh positif juga tidak signifikan kepada BM di kabupaten/kota Provinsi Sumatera Utara. 2). Varible PAD memiliki nilai signifikan 0,045 dengan jumlah $t_{\text {hitung }}-2,020$ dan jumlah $t_{\text {tabel }}$ sebesar -1,997756 dengan nilai signifikan sebesar 0,05 maka kesimpulannya ialah jumlah $-\mathrm{t}_{\text {hitung }}<-\mathrm{t}_{\text {tabel }}(-2,020<-1,997756)$ serta nilai signifikannya $<0,05$ maka $\mathrm{H}_{0}$ ditolak $\mathrm{H}_{\mathrm{a}}$ diterima. Maka bisa disimpulkan PAD mempunyai pengaruh negatif serta signifikan kepada BM di kabupaten/kota Provinsi Sumatera Utara. 3). Variable DB memiliki nilai signifikan 0,000 dengan nilai thitung sebesar 5,736 dan nilai $t_{\text {tabel }}$ sebesar 1,97756 dengan nilai signifikan sebessar 0,05. Maka kesimpulannya jumlah $t_{\text {hitung }}>\mathrm{t}_{\text {tabel }}(5,736>1,97756)$ serta nilai signifikannya $<0,05$ maka $\mathrm{H}_{0}$ ditolak $\mathrm{H}_{a}$ diterima. maka dinyatakan $\mathrm{DB}$ memiliki pengaruh positif serta signifikan kepada BM di kabupaten/kota Provinsi Sumatera Utara. 4). Variable SiLPA memliki jumlah signifikan 0,000 dengan jumlah $t_{\text {hitung }} 3,785$ dan nilai $t_{\text {tabel }} 1,97756$ serta nilai signifikan 0,05. Bisa dinyatakan ialah nilai $t_{\text {hitung }}>t_{\text {tabel }}(3,785>1,97756)$ maka $\mathrm{H}_{0}$ ditolak $\mathrm{H}_{\mathrm{a}}$ di terima. Dapat disimpulkan SiLPA memiliki pengaruh positif serta signifikan kepada BM di kabupaten/kota Provinsi Sumatera Utara.

\section{Pengaruh Produk Domestik Regional Bruto (PDRB) terhadap belanja modal}

Dari hasil pembahasan ini dapat menyatakan PDRB secara parsial tidak mempunyai pengaruh positif juga bukan signifikan kepada BM di Sumatera Utara pada tahun 20132017. Hasil dari penelitian ini tidak sama atas teori Adisasmita (2014:29) yang mengatakan PDRB yang besar selalu mempunyai BM yang besar. Artinya semakin naik tingkat pemberian otonomi bisa memberikan dampak besar dalam pertumbuhan ekonomi

Hasil ini berbeda dengan penelitian Hartati (2013) mengatakan PDRB berpengaruh kepada belanja modal yang berjudul Pengaruh Produk Domestik Regional Bruto, Pendapatan Asli Daerah, dan Dana Alokasi Umum Terhadap Belanja Modal di Kota Balikpapan, dimana tahun penelitian ini sampai 9 tahun.

\section{Pengaruh Pendapatan Asli Daerah (PAD) terhadap belanja modal}

Dari penelitian menggambarkan secara parsial PAD mempunyai pengaruh negatif dan signifikan kepada BM di Sumatera Utara tahun 2013-2017. Hal ini sama dengan teori Halim, (2014:172) yang menyatakan PAD berpengaruh kepada belanja modal, artinya apabila PAD sebuah daerah semakin bagus maka alokasi belanjanya semakin besar 
dimana setiap penerimaan daerah sangat berpengaruh penting dalam mengatur belanja daerah.

Hasil ini searah dengan pendapat dari penelitia Wardania (2013) berkata PAD berpengaruh kepada belanja modal dimana judul penelitiannya adalah Pengaruh Dana Alokasi Umum, Pendapatan Asli Daerah, Sisa Lebih Pembiayaan Anggaran, dan Luas Wilayah Terhadap Anggaran Belanja Modal (Studi Empiris Pada Kabupaten/Kota Di Pulau Jawa), dimana didalam penelitian ini sample yang digunakan sebanyak 104 Kabupaten/Kota.

\section{Pengaruh Dana Berimbang (DB) terhadap belanja modal}

Hasil ini menggambarkan secara parsial DB mempunyai pengaruh positif serta signifikan terhadap BM di Sumatera Utara pada tahun 2013-2017.

Hal ini searah dengan Siregar (2017:84) berkata dana berimbang mempunyai pengaruh kepada BM dan sifat BM sangat ditentukan oleh DB. Artinya penghasilan dari pusat dihitung oleh pemerintah daerah sebangai dana BM.

Hal tersebut tidak searah kepada peneliti terdahulu yang dibuat Sari dkk (2017) dana berimbang tidak mempunyai pengaruh kepada BM dengan judul Pengaruh Dana Perimbangan, Dana Sisa Lebih Perhitungan Anggaran dan Pendapatan Asli Daerah Terhadap Belanja Bodal dan Dampaknya Pada Pertumbuhan Ekonomi. Hal ini bisa saja terjadi dikarenakan jumlah sample yang berbeda.

\section{Pengaruh SiLPA terhadap belanja modal}

Hasil penelitian ini menyatakan secara parsial SiLPA memiliki pengaruh positif dan signifikan kepada BM di Sumatera Utara pada tahun 2013-2017. Hal ini searah dengan penelitian Sujarweni (2015:73) berkata SiLPA berpengaruh terhadap belanja modal. SiLPA dapat meningkatkan pembangunan infrastruktur yang mendorong pertumbuhan ekonomi suatu daerah. Hal ini menunjukkan bahwa dalam setiap anggaran BM dipengaruhi oleh akan SiLPA dalam pembangunan daerah.

Hal ini searaah dengan penelitian sebelumnya yang dibuat oleh Desi dkk (2018) mengatakan kalau SiLPA berpengaruh terhadap belanja modal, dengan judul Pengaruh SiLPA dan Ketergantungan Fiskal Terhadap Belanja Modal Kabupaten/Kota Dipulau Sumatera Dengan Klarifikasi Pemerintah Daerah Sebagai Pembeda, tempat penelitian dilakukan di Sumatera.

\section{KESIMPULAN DAN SARAN}

\section{Kesimpulan}

Secara parsial PDRB tidak berpengaruh signifikan dengan Belanja Modal pada Kabupaten/Kota Provinsi Sumatera Utara tahun 2013-2017. Secara parsial PAD berpengaruh signifikan dengan BM pada Kabupaten/Kota Provinsi Sumatera Utara tahun 2013-2017. Variabel Dana Berimbang secara parsial memiliki pengaruh signifikan dengan Belanja Modal pada Kabupaten/Kota Provinsi Sumatera Utara tahun 2013-2017. Variabel Sisa Lebih Pembiayaan Anggaran (SiLPA) secara parsial SiLPA berpengaruh Signifikan dengan BM pada Kabupaten/Kota Provinsi Sumatera Utara tahun 2013-2017. Secara simultan dapat menyimpulkan bahwa PAD, Dana Berimbang, serta SiLPA memiliki pengaruh signifikan dengan BM pada Kabupaten/Kota Provinsi Sumatera Utara tahun 2013-2017. Dan secara simultan PDRB tidak berpengaruh serta bukan signifikan dengan BM pada Kabupaten/Kota Provinsi Sumatera Utara tahun 2013-2017. 


\section{Saran}

Menurut hasil penelitian dapat disarankan oleh pengkaji sebagai berikut:1). Diharapkan bagi peneliti selanjutnya agar menambahkan variabel yang berbeda agar dapat dibandingkan dengan peneliti terdahulu. 2). Diharapkan bagi pemerintah hasil penelitian ini juga memberi masukan bagi pihak manajemen keuangan pemerintah juga dapat dijadikan untuk dasar dalam hal peningkatan kinerja keuangan. 3). Diharapkan hasil penelitian ini dapat memberikan atau dapan dijadikan sebagai referensi dalam penyajian ilmu pengetahuan bagi perpustakaan pengaruh produk domestik regional bruto, pendapatan asli daerah, dana berimbang, sisa lebih pembiayaan anggaran terhadap belanja modal.

\section{DAFTAR PUSTAKA}

Adisasmita, Rohardjo. (2014). Anggaran pendapatan dan belanja daerah. Cetakan Pertama. Graha Ilmu: Yogyakarta

Badan Pusat Statistik. (2020). Statistik keuangan pemerintah daerah Tahun 2016-2017. http://sumut.bps.go.id, Tanggal 23 Oktober 2019, Pukul 18.00 WIB

Desi Zeatifani, Syukri Abdullah (2018). Pengaruh SiLPA dan ketergantungan fiskal terhadap belanja modal Kabupaten/Kota di Pulai Sumatera dengan klasifikasi pemerintah daerah sebagai Pembeda. Skripsi. Fakultas Ekonomi Dan Bisnis Universitas Syiah Kuala: Banda Aceh

Erlina,Omar Sakti Rambe, Rasdianto. (2015). Akuntansi keuangan daerah berbasis akrual. Salemba Empat: Semarang

Gozhali, H. Imam. (2016). Aplikasi analisis multivariate dengan program IBM SPSS 21. Cetakan kedelapan. Badan Penerbit Universitas Diponegoro: Semarang

Hartati, Hariani Dwi. (2013). Pengaruh produk domestik regional bruto, pendapatan asli daerah, dan dana alokasi umum terhadap belanja modal di Kota Balikpapan. Journal Inovation in Business \& Economics, 4(2), 113-130

Halim,Abdul, (2013). Manajemen keuangan sektor publik. Salemba Empat: Jakarta

Nufus,Hayatun, Jhon Andra Asmara (2017) Pengaruh pendapatan sendiri dan dana perimbangan terhadap belanja modal dengan dana otonomi khusus sebagai pemoderasi pada Kabupaten/Kota Di Provinsi Aceh. Jurnal Fakultas Ekonomi dan Bisnis Universitas Syiah Kuala. 2(3), 1-9

Wardania, Tika Kusuma. (2013). Pengaruh dana alokasi umum, pendapatan asli daerah, sisa lebih pembiayaan anggaran, dan luas wilayah terhadap anggaran belanja modal (Studi empiris pada Kabupaten/Kota di Pulau Jawa). Skripsi. Fakultas Ekonomi dan Bisnis Universitas Muhammadiyah Surakarta: Surakarta.

Rizal,Yani., \& Erpita .(2019). Pengaruh pendapatan asli daerah terhadap belanja modal di Kota Langsa. Jurnal Samudra Ekonomika, 3(1), 74-83. https://doi.org/ 10.1234/jse.v3i1.1296.

Sugiyono. (2010). Metode penelitian kuantitatif, kualitatif, dan $R \& D$. Alfabeta: Bandung Sujarweni,V. Wiratna. (2015). Akuntansi Sektor Publik. Yogyakarta: Pustaka Baru Press.

Susanti,Susi, Heru Fahlevi (2016) Pengaruh pendapatan asli daerah, dana alokasi umum, dan dana bagi hasil terhadap belanja modal (Studi pada Kabupaten/Kota di Wilayah Aceh).Jurnal Ilmiah Ekonomi Akuntansi (JIMEKA), 1(1), 183-191

Sari, Nurmala, Gustian Djuanda., \& Sarwani (2018) Pengaruh dana perimbangan, dana Sisa Lebih Pembiayaan Anggaran (SiLPA) dan pendapatan asli daerah terhadap belanja modal dan dampaknya pada pertumbuhan ekonomi. Prosiding Seminar Ilmiah Nasional, Pascasarjana Universitas Pamulang, 491-506 